\title{
Oxidative stress and antioxidative defense in cephalopods: a function of metabolic rate or age?
}

\author{
Susanne Zielinski, Hans-O. Pörtner * \\ Alfred-Wegener-Institut für Polar- und Meeresforschung, Biologie I/Ökophysiologie, Columbusstrasse, 27568 Bremerhaven, Germany
}

Received 7 June 1999; received in revised form 22 September 1999; accepted 27 September 1999

\begin{abstract}
Activities of the antioxidative enzymes superoxide dismutase (SOD), catalase, glutathione peroxidase (GPX) and glutathione reductase (GR) were measured in the cephalopods Sepia officinalis and Lolliguncula brevis. Maximal enzyme activities were higher in gill tissue than in the mantle musculature of both species. Activities were generally lower in tissues of $L$. brevis than in S. officinalis. Comparison with other ectothermic animals showed both cephalopod species to have a low enzymatic antioxidative status despite their high metabolic rate. Furthermore, changes in antioxidative enzyme activities were measured in the cuttlefish $S$. officinalis with increasing age. The concentrations of malondialdehyde (MDA) and lipofuscin were determined as indicators of lipid peroxidation. Investigated animals were between 1.5 months and over 12 months old. Changes of antioxidative enzyme activities with age were not uniform. SOD and GPX activities increased with age, while catalase activity declined. In contrast, GR activity remained almost unchanged in all age groups. The low level of antioxidative defense might allow for the significant age-induced rise in MDA levels in gills and mantle musculature and for the increase in lipofuscin levels in mantle and brain tissue. It might thereby contribute to increased oxidative damage and a short life span in these cephalopods. (C) 2000 Elsevier Science Inc. All rights reserved.
\end{abstract}

Keywords: Ageing; Catalase; Life expectancy; Lipofuscin; Lolliguncula brevis; Malondialdehyde; Metabolic rate; Sepia officinalis; Superoxide dismutase

\section{Introduction}

Oxygen radicals and hydrogen peroxide $\left(\mathrm{H}_{2} \mathrm{O}_{2}\right)$ are continually produced as biproducts of aerobic metabolism and may cause oxidative damage to lipids, proteins and nucleic acids (Halliwell and Gutteridge, 1989; Stadtman, 1992). Although all classes of macromolecules are susceptible to radical attack, polyunsaturated fatty acids are espe-

\footnotetext{
* Corresponding author. Tel.: + 49-471-4831307; fax: + 49471-4831149.

E-mail address: hpoertner@awi-bremerhaven.de (H.-O. Pörtner)
}

cially sensitive to oxidation owing to their conjugated double bond structures (Storey, 1996). A radical attack on lipids leads to the formation of lipid-hydroperoxides (lipid-OOH; Leibovitz and Siegel, 1980; Storey, 1996), which can decompose to yield alkanes, alkenes, ketones and aldehydes. The most important aldehyde produced is malondialdehyde (MDA), which forms Schiff bases with amines of proteins, phospholipids, and nucleic acids. The products of these reactions are extremely large fluorescent biomolecules, named age pigments or lipofuscin, which are not digested in the lysosomes because of unusual structures. They therefore accumulate with age (Leibovitz and Siegel, 1980; Halliwell and Gutteridge, 1989). 
Oxidative damage is counteracted by antioxidant defense systems and repair mechanisms. Enzymes catalysing the breakdown of oxygen radicals and $\mathrm{H}_{2} \mathrm{O}_{2}$ serve as primary antioxidants. Superoxide $\left(\mathrm{O}_{2}^{-}\right)$generated in peroxisomes and mitochondria is converted to hydrogen peroxide by the enzyme superoxide dismutase (SOD: $\mathrm{O}_{2}^{-}$ $+2 \mathrm{H}_{2} \mathrm{O} \rightarrow 2 \mathrm{H}_{2} \mathrm{O}_{2}$ ). Catalase removes $\mathrm{H}_{2} \mathrm{O}_{2}$ via $2 \mathrm{H}_{2} \mathrm{O}_{2} \rightarrow 2 \mathrm{H}_{2} \mathrm{O}+\mathrm{O}_{2}$. Among low molecular weight antioxidants, vitamins and glutathione are considered to be important (Elstner, 1990). The reduced form of glutathione (GSH) may be oxidised by $\mathrm{H}_{2} \mathrm{O}_{2}$ or organic peroxides to oxidised glutathione (GSSG) either spontaneously or via glutathione peroxidase (GPX) catalysis. Compensatory reduction of GSSG is catalysed by glutathione reductase (GR): GSSG + NADPH + $\mathrm{H}^{+} \rightarrow 2 \mathrm{GSH}+\mathrm{NADP}^{+}$.

Despite antioxidant defense systems and repair mechanisms oxidative stress appears to be one of the most important factors contributing to aging (Harman, 1956; Ku et al., 1993; Sohal and Weindruch, 1996). For example, the progressive accumulation of damaged protein molecules as a function of age may significantly contribute to the inability of individual cells and therefore the entire organism to fulfil various physiological functions (Reiss and Gershon, 1976). The accumulation of defective macromolecules with age is either caused by an age related increase of oxidative damage and/or by the loss of the ability to repair or degrade these molecules (Stadtman, 1992).

The maximal life span potential (MLSP) of a species might be influenced by its metabolic rate. An increased metabolic rate appears to have a negative influence on the life span in a way, in that it causes an increase in radical production and therewith oxidative damage (Sohal, 1981). This is supported by different investigations on mammalian species (Sohal et al., 1989; Ku et al., 1993). Animals with the highest rates of oxygen consumption displayed the highest mitochondrial production of superoxide and $\mathrm{H}_{2} \mathrm{O}_{2}$. At the same time, the production of reactive oxygen species (ROS) was negatively correlated with MLSP, that means, species with the highest life span potential showed the lowest rate of radical formation. A correlation of life span and ROS production was also found for the housefly Musca domestica. Flies with a lower metabolic rate at lower activity levels lived longer than more active specimens (Sohal and Donato, 1979).
Among marine invertebrates, cephalopods display the highest metabolic rates. Squids even have metabolic rates higher than fishes of similar size and life style (O’Dor and Weber, 1986). High metabolic rates correspond with high growth rates in cephalopods. All cephalopod species investigated except for Nautilus species have higher growth rates than poikilothermic vertebrates (fishes, amphibians, reptiles), even reaching growth rates comparable to those of mammals (Calow, 1987). In contrast to mammals, high metabolic and growth rates of cephalopods are linked to a short life expectancy of between less than 1 year and a maximum of $\sim 3$ years (Pörtner, 1994, 1997). These considerations led us to ask whether oxidative stress might be a factor contributing to the short life expectancies of cephalopods and whether the antioxidative capacity of cephalopods is adapted to match a possibly higher radical generation at high metabolic rate. For this purpose, the activities of antioxidative enzymes (SOD, catalase, GR and GPX) were compared in cuttlefish Sepia officinalis and the squid Lolliguncula brevis. The adult squid are about 20 -fold smaller and possess a two times higher metabolic rate than the cuttlefish. Furthermore, oxidative damage was investigated by analysing the levels of malondialdehyde and lipofuscin in different age groups of laboratory reared S. officinalis. Constant breeding conditions guarantee that aging occurs continuously and is not influenced by variable and unknown conditions in the natural environment.

\section{Material and methods}

\subsection{Animals}

S. officinalis were obtained from the Marine Biomedical Institute of the University of Texas, Galveston, TX, USA, where this species has been bred and grown for several consecutive generations. They were kept at a salinity of $35 \%$ at temperatures of $20-22^{\circ} \mathrm{C}$ and fed regularly on small fishes and mysid shrimps. This species reaches a maximum age of 2 years in its natural environment (von Boletzky, 1983), while a maximum age of 14 months was achieved in captivity (Forsythe et al., 1994). This may be related to the constant and high maintenance temperatures in the laboratory, whereas the life span may be 
significantly extended during seasonal cooling in the field (Section 4). Animals of the following age groups were available for experiments: 1.5 months (5.3-23.7 g); 2.5 months (27.0-142.7 g); 7 months (193.5-334.4 g); 10 months $(469.8-773.0 \mathrm{~g})$ and 12 months (805.7-963.2 g) old.

Brief squid (L. brevis Blainville, 3.1-18.9 g) were caught in April 1995 in the Galveston Ship Channel and Galveston Harbor by fishermen of the Marine Biomedical Institute of the University of Texas, Galveston, TX, USA and kept in aquaria with recirculating natural sea water under conditions similar to those in the natural habitat $\left(24-25 \%\right.$ at $\left.20-22^{\circ} \mathrm{C}\right)$. The squid were allowed to adjust to the aquarium for at least $48 \mathrm{~h}$. The animals were fed fish and mysid shrimp, but not during the last $24 \mathrm{~h}$ prior to sampling.

\subsection{Samples}

S. officinalis was anaesthetised with $7.5 \%$ $\mathrm{MgCl}_{2}$ (w/v) in seawater, while for L. brevis $4.7 \%$ $\mathrm{MgCl}_{2}$ (w/v) was used (Messenger et al., 1985). The mantle of the animals was opened by a ventral incision. In case of $S$. officinalis blood was collected from the vena cava, the systemic heart and the gill hearts. Afterwards samples of different tissues (mantle, gills and brain) were taken. SOD and GPX activity as well as lipofuscin concentrations were immediately measured in freshly sampled tissues. All other enzymes and malondialdehyde concentrations were measured in samples that had previously been freeze-clamped and stored in liquid nitrogen.

\subsection{Analyses}

\subsubsection{Preparation of tissue extracts for enzyme assays}

For the evaluation of catalase and glutathione reductase activity, frozen tissue samples were ground under liquid nitrogen. Homogenates for the measurement of superoxide dismutase and glutathione peroxidase were prepared by using freshly excised tissue, which was minced using a pair of scissors. All samples were homogenised $1: 3-1: 5(\mathrm{w} / \mathrm{v})$ in the respective homogenisation buffer (see below) by using a micro homogenizer (Biospec Products, Bartlesville, OK, USA). After centrifugation $(10 \mathrm{~min}$ at $14000 \times g)$ enzyme activities were measured in the supernatant. All enzyme assays were tested with commercial enzymes obtained from Sigma (St. Louis, USA).

\subsubsection{Catalase}

Catalase activity (EC 1.11.1.6) was determined after Aebi (1985). A $50 \mathrm{mmol} 1^{-1}$ potassium phosphate buffer (pH 7.0) containing one part of $1 \%$ Triton-X100 in water and ten parts of buffer was used as homogenisation buffer. The assay contained $50 \mathrm{mmol}^{-1}$ potassium phosphate buffer ( $\mathrm{pH} 7.0$ ) and $12.1 \mathrm{mmol} \mathrm{1}^{-1} \mathrm{H}_{2} \mathrm{O}_{2}$ as a substrate. The decay of peroxide was monitored at $240 \mathrm{~nm}$ and $25^{\circ} \mathrm{C}$. Under the assay conditions applied, $1 \mathrm{U}$ catalase decomposes $1 \mu \mathrm{mol} \mathrm{H}_{2} \mathrm{O}_{2}$ $\min ^{-1}$.

\subsubsection{Superoxide dismutase (SOD)}

SOD (EC 1.15.1.1) activity was determined after Marklund and Marklund (1974), using 50 mmol $1^{-1}$ Tris-succinate buffer ( $\mathrm{pH}$ 8.2) for homogenisation. The autoxidation of a pyrogallol solution $\left(8 \mathrm{mmol}^{-1}\right)$ in air saturated $50 \mathrm{mmol}$ $1^{-1}$ Tris-succinate buffer ( $\mathrm{pH}$ 8.2) measured at $420 \mathrm{~nm}$ and $25^{\circ} \mathrm{C}$ is inhibited $50 \%$ by $1 \mathrm{U}$ of SOD (SOD-U).

\subsubsection{Glutathione reductase (GR)}

A $120 \mathrm{mmol}^{-1}$ phosphate buffer (pH 7.2) was used as homogenisation buffer. GR (EC 1.6.4.2) activity was determined spectrophotometrically in the supernatant at $25^{\circ} \mathrm{C}$ and $339 \mathrm{~nm}$ using a method modified after Goldberg and Sparner (1987). The assay contained (in mmol $1^{-1}$ ) 100 Tris buffer (pH 8.2), 0.94 EDTA, 4.6 GSSG and 0.16 NADPH.

\subsubsection{Glutathione peroxidase (GPX; EC 1.11.1.9)}

Tissue was homogenised in Tris- $\mathrm{HCl}$ buffer (20 mmol $1^{-1}, \mathrm{pH}$ 7.6) including $1 \mathrm{mmol} 1^{-1}$ EDTA and $1 \mathrm{mmol} 1^{-1}$ dithiotreitol. The assay contained (in mmol $1^{-1}$ ) 100 potassium phosphate buffer (pH 7.0), $10 \mathrm{GSH}, 1.5 \mathrm{NADPH}, 1.5 \mathrm{H}_{2} \mathrm{O}_{2}$ and 10 $\mathrm{U} \mathrm{ml}^{-1} \mathrm{GR}$. The oxidation of NADPH was followed spectrophotometrically at $339 \mathrm{~nm}$ (Günzler and Flohé, 1985). Under the assay conditions applied, 1 U GPX or GR activity, respectively, is defined as a decrease of $1 \mu \mathrm{mol}$ NADPH $\mathrm{min}^{-1}$.

\subsubsection{Determination of malondialdehyde (MDA)}

MDA concentrations were assayed in mantle and gill tissue of $S$. officinalis according to Uchiyama and Mihara (1978). Tissue was ground under liquid nitrogen and homogenised in 1:5 $(\mathrm{w} / \mathrm{v}) \quad 0.2 \% \quad \mathrm{H}_{3} \mathrm{PO}_{4}$. Then $0.4 \mathrm{ml}$ of the homogenate was mixed with $0.4 \mathrm{ml}$ of $1 \%$ thiobarbi- 
turic acid (TBA). The TBA forms a complex with MDA. Individual blanks were prepared by replacing the TBA solution with $3 \mathrm{mmol}^{-1}$ $\mathrm{HCl}$. The $\mathrm{pH}$ of all samples was adjusted to 1.6 with either $10 \mathrm{~mol} 1^{-1} \mathrm{NaOH}$ or $12 \mathrm{~mol} \mathrm{1}^{-1}$ $\mathrm{HCl}$. Afterwards, the samples were heated to $100^{\circ} \mathrm{C}$ for $15 \mathrm{~min}$. After cooling to room temperature, $1.5 \mathrm{ml}$ butanol were added to samples and blanks, which were then mixed vigorously to transfer the MDA-acid-complex into the butanol phase. This phase was separated by centrifugation and the absorbance of the MDA-acid-complex was measured as the difference between 532 and $600 \mathrm{~nm}$. The concentration was quantified by using the TBA-MDA extinction coefficient $\left(\varepsilon=156 \mathrm{mmol} 1^{-1} \mathrm{~cm}^{-1}\right)$.

\subsubsection{Assay of lipofuscin}

Mantle and brain tissue of $S$. officinalis were ground under liquid nitrogen and homogenised in a chloroform-methanol mixture $(1: 20, \mathrm{w} / \mathrm{v})$. After centrifugation for $10 \mathrm{~min}$ at $2000 \times g$ (modified after Sheldahl and Tappel, 1974; Ettershank, 1983, 1984), lipofuscin can be found in the chloroform phase. In this phase an emission spectrum between 350 and $550 \mathrm{~nm}$ was obtained at an excitation wavelength of $350 \mathrm{~nm}$ using a Shimadzu RF 5000 U fluorimeter. The luminescence of the sample was determined at the emission maximum (Nicol, 1987) at $435 \mathrm{~nm}$ in case of $S$. officinalis. Lipofuscin concentrations are expressed as relative fluorescence intensity (RFI) according to Hill and Womersley (1991), using $0.1 \mu \mathrm{g}$ quinine per $\mathrm{ml} 1 \mathrm{~N} \mathrm{H}_{2} \mathrm{SO}_{4}$ as a standard.

\subsection{Statistics}

The significance of differences between different age groups of $S$. officinalis was tested by one-way analysis of variance (ANOVA) and Student-Newman-Keul's posthoc tests. Data are given as means \pm S.D. Linear regressions were calculated to evaluate whether activities of antioxidative enzymes and oxygen consumption rates of different species are correlated. Outliers were eliminated from the data set by use of Pearson and Hartley's test. In all cases, $P<0.05$ was accepted to indicate a significant difference.

\section{Results}

Figs. 1 and 2 show the activities of the enzymes SOD, catalase, GPX and GR in the mantle musculature and gill tissues of $S$. officinalis in relation to the age of the animals. For all investigated enzymes higher activities were found in gill tissue compared to mantle tissue. In three of four enzymes, activities changed with increasing age. SOD activity increased twofold in the mantle and sixfold in gill tissue with maximal activities in animals 12 months old (mantle: $157.2 \pm 38.9$ SOD-U $\mathrm{g}^{-1}$ fresh weight; gills: $491.5 \pm 234.4$ SOD-U $\mathrm{g}^{-1}$ fresh weight; Fig. 1). Likewise, GPX activity in the gill tissue was significantly and 2.5-fold increased in the oldest animals, while only a slight, insignificant rise was seen in the mantle musculature (Fig. 2). Catalase activity in the mantle musculature dropped from $20.6 \pm 25.3 \mathrm{U} \mathrm{g}^{-1}$ fresh weight in the youngest animals to values below detection limits in the oldest animals. A transient increase of activity was found in gill tissue of animals 2.5 and 7 months old. Catalase activity in gills of the oldest animals was significantly below levels found in the youngest animals (Fig. 1). GR activity did not change with age. Values remained $\sim 0.04 \quad \mathrm{U} \mathrm{g}^{-1}$ fresh weight in the mantle and $\sim 0.29 \mathrm{U} \mathrm{g}^{-1}$ fresh weight in the gill tissue (Fig. 2).

Similar to $S$. officinalis, enzyme activities were higher in the gills than in the mantle musculature of L. brevis (Table 1). In general, no catalase or GR activity could be found in the mantle of L. brevis. Activities were always lower in L. brevis than in S. officinalis.

Fig. 3 displays the concentration of malondialdehyde (MDA) in tissues of S. officinalis. The highest concentration of $234.8 \pm 155.5 \mathrm{nmol} \mathrm{g}^{-1}$ fresh weight was reached in the mantle musculature of animals 10 months old. This increase was significant compared to animals $1.5,2.5$ and 7 months old. In 12 months old Sepia, the concentration had returned to low values. Furthermore, a transient decrease in MDA concentrations was found in the gill tissue of 7-month-old compared to the youngest animals, while the concentration was significantly increased in older compared to the youngest specimens. Lipofuscin concentrations rose significantly with increasing age in both mantle and gill tissue (Fig. 3). 
Table 1

Comparison of antioxidative enzyme activities and the oxygen consumption rates of selected species ${ }^{\mathrm{a}}$

\begin{tabular}{|c|c|c|c|c|c|c|c|c|}
\hline Species & Tissue & $\begin{array}{l}\text { SOD (SOD-U } \\
\mathrm{g}^{-1} \text { fresh wt.) }\end{array}$ & $\begin{array}{l}\text { Catalase ( } \mathrm{U} \mathrm{g}^{-1} \\
\text { fresh wt.) }\end{array}$ & $\begin{array}{l}\text { GPX }\left(\mathrm{U} \mathrm{g}^{-1}\right. \\
\text { fresh wt.) }\end{array}$ & $\begin{array}{l}\mathrm{GR}\left(\mathrm{U} \mathrm{g}^{-1}\right. \\
\text { fresh wt. })\end{array}$ & $\begin{array}{l}\mathrm{M}_{\mathrm{O}_{2}}\left(\mu \mathrm{mol} \mathrm{O} \mathrm{O}_{2}\right. \\
\left.\mathrm{g}^{-1^{2}} \mathrm{~h}^{-1}\right)\end{array}$ & $T\left({ }^{\circ} \mathrm{C}\right)$ & Reference \\
\hline \multirow[t]{2}{*}{ S. officinalis } & Gills & $491.5 \pm 234.4$ & $416.0 \pm 195.2$ & $0.26 \pm 0.03$ & $0.30 \pm 0.06$ & $8.9^{\mathrm{c}}$ & 17 & This study \\
\hline & Mantle & $157.2 \pm 38.9$ & $20.6 \pm 25.3$ & $0.03 \pm 0.00$ & $0.04 \pm 0.03$ & & & \\
\hline \multirow[t]{2}{*}{ L. brevis } & Gills & $99.4 \pm 28.9$ & $255.7 \pm 106.9$ & $0.04 \pm 0.04$ & $0.08 \pm 0.02$ & $21.0^{\mathrm{d}}$ & 20 & This study \\
\hline & Mantle & $88.0 \pm 25.1$ & $0.0 \pm 0.0$ & $0.01 \pm 0.01$ & $0.00 \pm 0.00$ & & & \\
\hline \multirow[t]{3}{*}{ Mussel (M. edulis) } & Gills & ND & ND & $0.60 \pm 0.03$ & ND & & & Gamble et al., 1995 \\
\hline & Muscle & ND & ND & $0.72 \pm 0.24$ & & $0.14^{\mathrm{e}}$ & 20 & \\
\hline & DG & $615 \pm 52$ & $5870 \pm 1060$ & $0.60 \pm 0.15$ & & & & \\
\hline \multirow{3}{*}{$\begin{array}{l}\text { Scallop (Pecten max- } \\
\text { imus) }\end{array}$} & Gills & ND & ND & $0.45 \pm 0.15$ & ND & & & Gamble et al., 1995 \\
\hline & Muscle & $\mathrm{ND}$ & ND & $0.29 \pm 0.12$ & & $8.9-11.2^{\mathrm{f}}$ & 10 & \\
\hline & DG & $324 \pm 6$ & $36100 \pm 600$ & & & & & \\
\hline \multirow{3}{*}{$\begin{array}{l}\text { Shore crab (Carcinus } \\
\text { maenas) }\end{array}$} & Gills & ND & ND & $0.02 \pm 0.01$ & ND & & & Gamble et al., 1995 \\
\hline & Muscle & ND & ND & $0.11 \pm 0.02$ & & $1.8 \pm 0.1^{\mathrm{g}}$ & 18 & \\
\hline & HP & $173 \pm 10$ & $280 \pm 110$ & & & & & \\
\hline \multirow{2}{*}{$\begin{array}{l}\text { Clam }^{\mathrm{b}} \text { (Calyptogena } \\
\text { magnifica) }\end{array}$} & Gills & 495 & 0 & 0.14 & ND & $1.6 \pm 0.8^{\mathrm{h}}$ & 8 & Blum and Fridovich, 1984 \\
\hline & Muscle & 795 & 0 & 0.26 & & & & \\
\hline $\begin{array}{l}\text { Intertidal worm }{ }^{\mathrm{b}}(S . \\
\text { nudus })\end{array}$ & BWM & $2540 \pm 1250$ & $996 \pm 275$ & ND & ND & $0.7-0.8^{\mathrm{i}}$ & 15 & $\begin{array}{l}\text { Buchner, Abele, Pörtner, un- } \\
\text { published }\end{array}$ \\
\hline \multirow{2}{*}{$\begin{array}{l}\text { Lugworm }^{\mathrm{b}}(A \text {. } \\
\text { marina })\end{array}$} & BWM & $860 \pm 423$ & $1210 \pm 360$ & ND & $0.56 \pm 0.18$ & $1.31 \pm 1.01^{\mathrm{j}}$ & 10 & Buchner et al., 1996 \\
\hline & $\mathrm{CG}$ & $2670 \pm 675$ & $69300 \pm 34500$ & & $4.95 \pm 1.35$ & & & \\
\hline $\begin{array}{l}\text { Polychaete (H. fili- } \\
\text { formis) }\end{array}$ & Whole animal & $2170 \pm 610$ & $1190 \pm 260$ & & & $0.3 \pm 0.1$ & 10 & Abele et al., 1998 \\
\hline $\begin{array}{l}\text { Polychaete }^{\mathrm{b}}(N . d i- \\
\text { versicolor })\end{array}$ & Whole animal & 660 & 5070 & ND & ND & $6.3^{\mathrm{k}}$ & 10 & Abele-Oeschger et al., 1994 \\
\hline \multirow[t]{2}{*}{ Cod (G. morhua) } & Gills & $1640 \pm 140$ & $4140 \pm 710$ & $2.88 \pm 0.44$ & ND & $3.9^{1}$ & 15 & Lemaire et al., 1993 \\
\hline & Muscle & $175 \pm 17$ & $260 \pm 50$ & $0.30 \pm 0.06$ & & & & \\
\hline Trout $(S$. trutta $)$ & Liver & 2700 & 16700 & 10 & 0.15 & 10.1 & 25 & López-Torres et al., 1993 \\
\hline Frog $(R$. perezi $)$ & Liver & 8200 & 110000 & 10 & 1.0 & $3.0 \pm 0.2$ & 25 & López-Torres et al., 1993 \\
\hline Guinea pig & Liver & 25000 & 90000 & 40 & 4.0 & $30.4 \pm 1.2$ & 25 & López-Torres et al., 1993 \\
\hline Rat (Wistar) & Liver & 17700 & 76700 & 220 & 6.0 & $35.2 \pm 2.0$ & 25 & López-Torres et al., 1993 \\
\hline Mouse (OF1) & Liver & ND & 26700 & $\mathrm{ND}$ & 3.8 & 115.5 & 25 & López-Torres et al., 1993 \\
\hline
\end{tabular}


Table 1

Comparison of antioxidative enzyme activities and the oxygen consumption rates of selected species ${ }^{\mathrm{a}}$

\begin{tabular}{|c|c|c|c|c|c|c|c|c|}
\hline Species & Tissue & $\begin{array}{l}\text { SOD (SOD-U } \\
\mathrm{g}^{-1} \text { fresh wt.) }\end{array}$ & $\begin{array}{l}\text { Catalase }\left(\mathrm{U} \mathrm{g}^{-1}\right. \\
\text { fresh wt.) }\end{array}$ & $\begin{array}{l}\text { GPX ( } \mathrm{U} \mathrm{g}^{-1} \\
\text { fresh wt. })\end{array}$ & $\begin{array}{l}\mathrm{GR}\left(\mathrm{U} \mathrm{g}^{-1}\right. \\
\text { fresh wt.) }\end{array}$ & $\begin{array}{l}\mathrm{M}_{\mathrm{O}_{2}}\left(\mu \mathrm{mol} \mathrm{O} \mathrm{O}_{2}\right. \\
\left.\mathrm{g}^{-1^{2}} \mathrm{~h}^{-1}\right)\end{array}$ & $T\left({ }^{\circ} \mathrm{C}\right)$ & Reference \\
\hline $\begin{array}{l}\text { Pigeon (Columbia } \\
\text { livia) }\end{array}$ & Liver & 29100 & 26700 & 10 & 3.8 & $67 \pm 4.3$ & 25 & López-Torres et al., 1993 \\
\hline
\end{tabular}

${ }^{\text {a }} T$ is the temperature at which $\mathrm{M}_{\mathrm{O}_{2}}$ was determined; BWM, body wall musculature; CG, chloragog; DG, digestive gland; HP, hepatopancreas; ND, no data available. $S$. officinalis, $n=3-11 ; L$. brevis, $n=4-6$; values are means \pm S.D.

${ }^{\mathrm{b}}$ Data were converted from $\mathrm{U} \mathrm{mg}^{-1}$ protein to $\mathrm{U} \mathrm{g}^{-1}$ fresh weight with the assumption of a mean protein concentration of $\sim 150 \mathrm{mg}$ protein $\mathrm{g}^{-1}$ fresh weight as found for fish (Foster et al., 1993).

${ }^{\mathrm{c}}$ References for oxygen consumption: Johansen et al., 1982;

${ }^{\mathrm{d}}$ Finke et al., 1996;

e Newell and Bayne, 1973;

${ }^{\mathrm{f}}$ Brand and Roberts, 1973;

g Taylor et al., 1977;

${ }^{\text {h }}$ Arp et al., 1984;

i Pörtner et al., 1985;

${ }^{\mathrm{j}}$ Sommer, 1998;

${ }^{\mathrm{k}}$ Kristensen, 1983;

${ }^{1}$ Boutilier, 1998. 


\section{Discussion}

4.1. Oxidative damage and antioxidative defense in relation to metabolic rate

In both investigated cephalopods, S. officinalis and L. brevis, higher activities of antioxidative enzymes were found in the gill tissues compared to the mantle musculature. This is similar to findings in cod, Gadus morhua (Lemaire et al., 1993) and might be due to the fact that the gills are exposed to higher (ambient and arterial) oxygen concentrations than other tissues, possibly leading to a higher rate of radical production. Hence, a higher level of protection would be necessary.
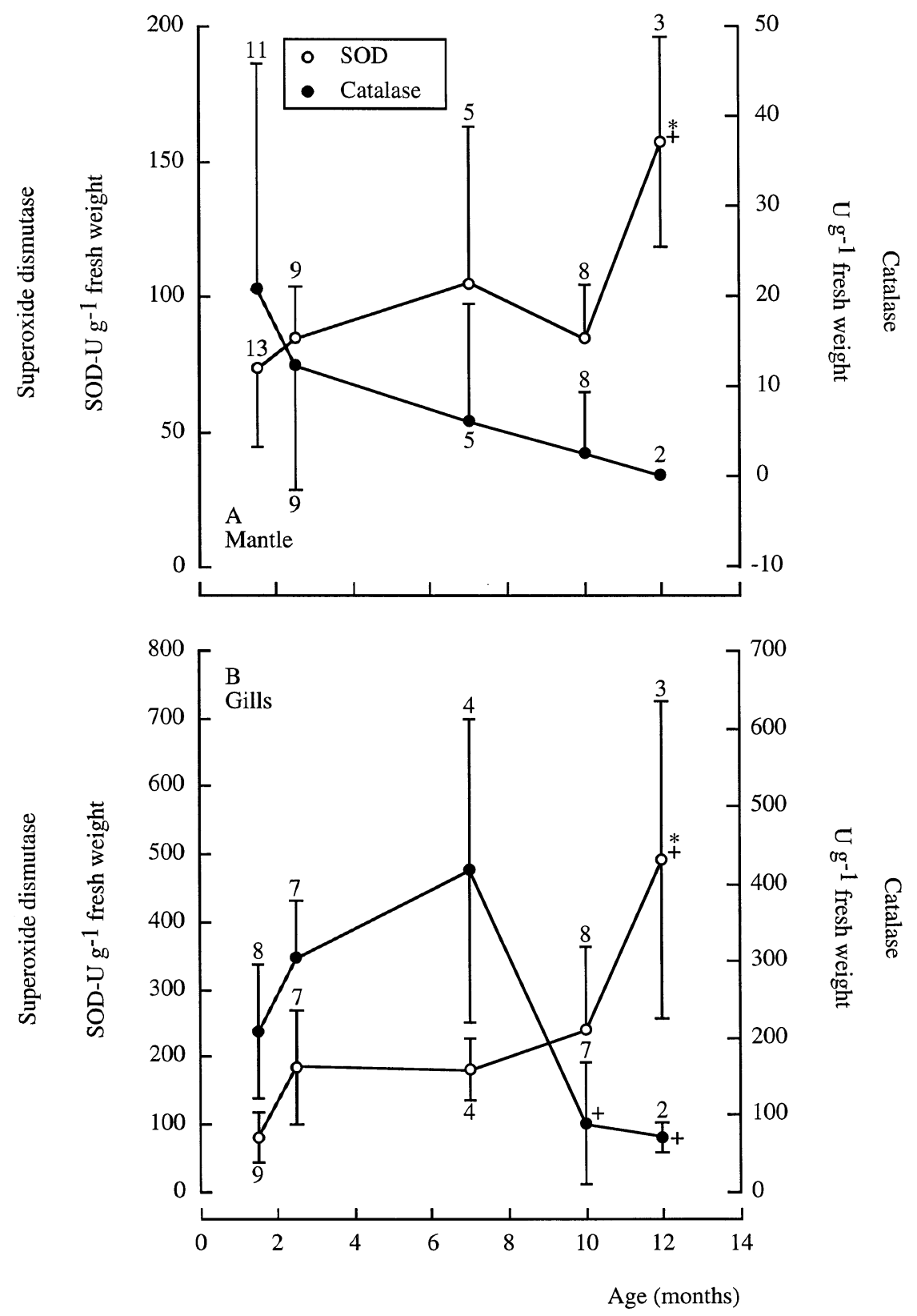

Fig. 1. Activities of superoxide dismutase and catalase in (A) mantle musculature and (B) gill tissue of different age groups of $S$. officinalis. (* Significantly different from animals 1.5 months old; + significantly different from animals 2.5 months old; numbers on top of bars $=n$; values are means \pm S.D., or \pm range for $n=2$ ). 

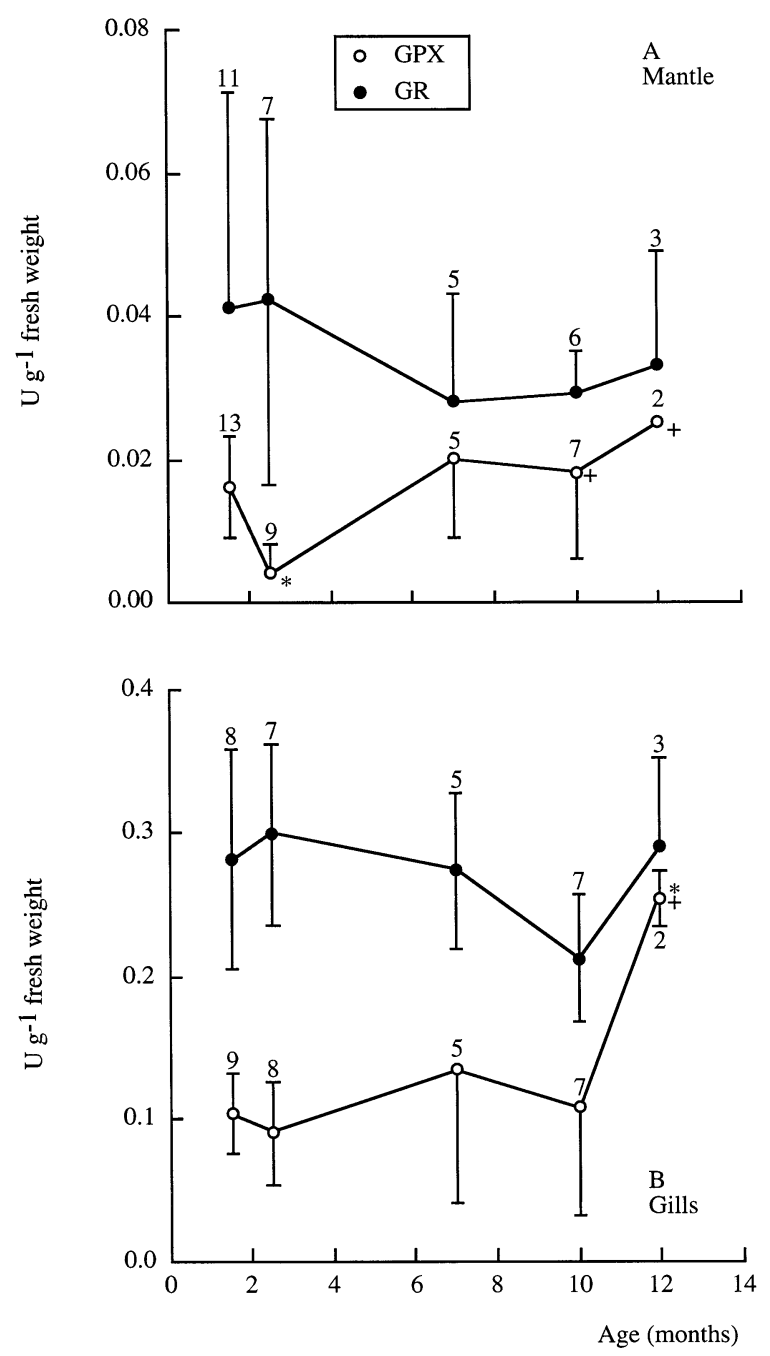

Fig. 2. Activities of glutathione peroxidase and glutathione reductase in (A) mantle musculature and (B) gill tissue of different age groups of $S$. officinalis. (* Significantly different from animals 1.5 months old; + significantly different from animals 2.5 months old; for further explanation see Fig. 1).

Differences in enzyme activities are not only found between mantle and gill tissue of cephalopods but vary in general between tissues as shown in Table 1. This should be taken into account when comparing antioxidative status. For some species, a high antioxidative status was found in some internal organs like the digestive gland. The evaluation of the antioxidative capacity of the digestive gland was not possible for the cephalopods since the color of this tissue interfered with the assay. Nevertheless, the highest level of antioxidative protection found in a species will be used for further comparison assuming that tissues with the highest levels are the most important in antioxidative defense.

Comparison between the two cephalopod species reveals that enzyme activities in L. brevis are 2- to 5-fold lower than the maximal activities found in $S$. officinalis despite the twofold higher metabolic rate in L. brevis. In addition, L. brevis displays a shorter life expectancy of $\sim 1$ year (Hixon et al., 1981) compared to S. officinalis, which survives up to 2 years in its natural environment (von Boletzky, 1983). This might be a first indicator that the level of antioxidative protection is correlated with the life expectancy of cephalopods. Further comparison (Table 1)
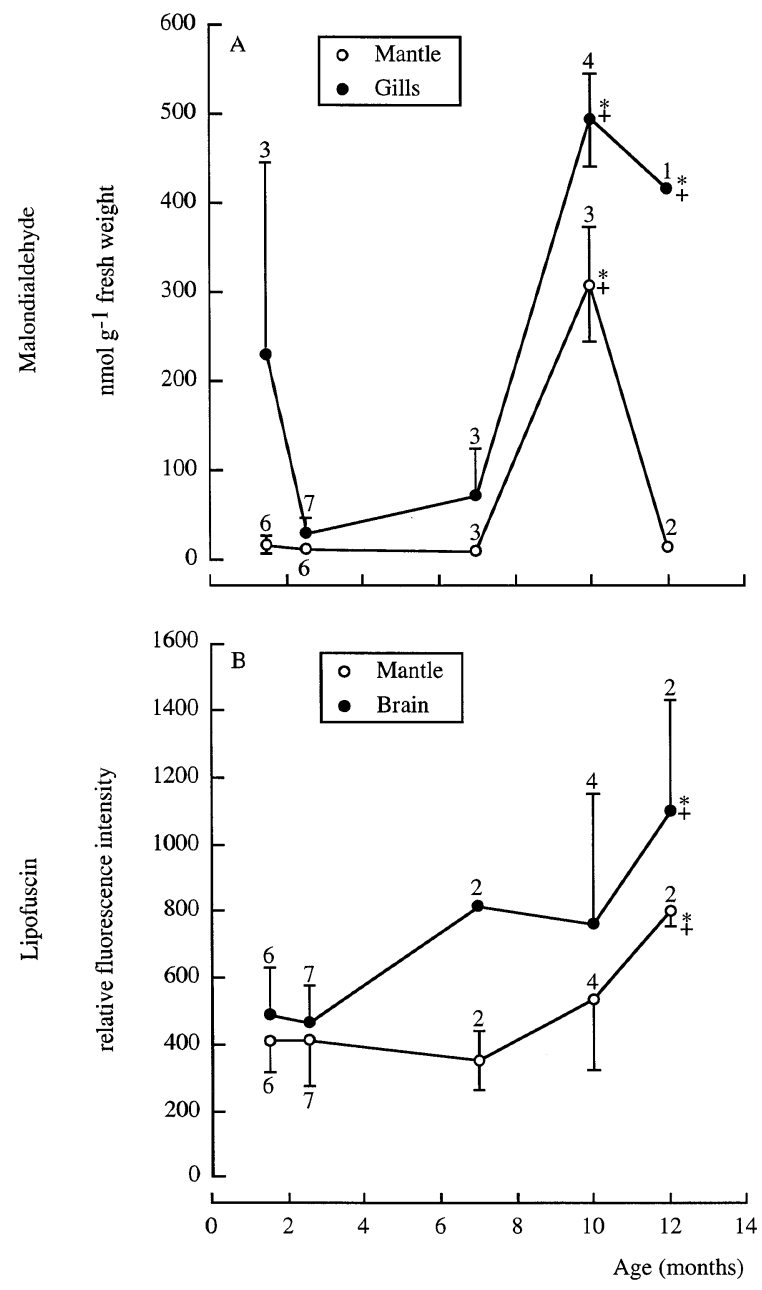

Fig. 3. The concentration of (A) malondialdehyde in mantle and gill tissue and (B) lipofuscin in mantle and brain tissue of S. officinalis in relation to the age of the animals. (* Significantly different from animals 1.5 months old; + significantly different from animals 2.5 and 7 months old; for further explanations see Fig. 1). 


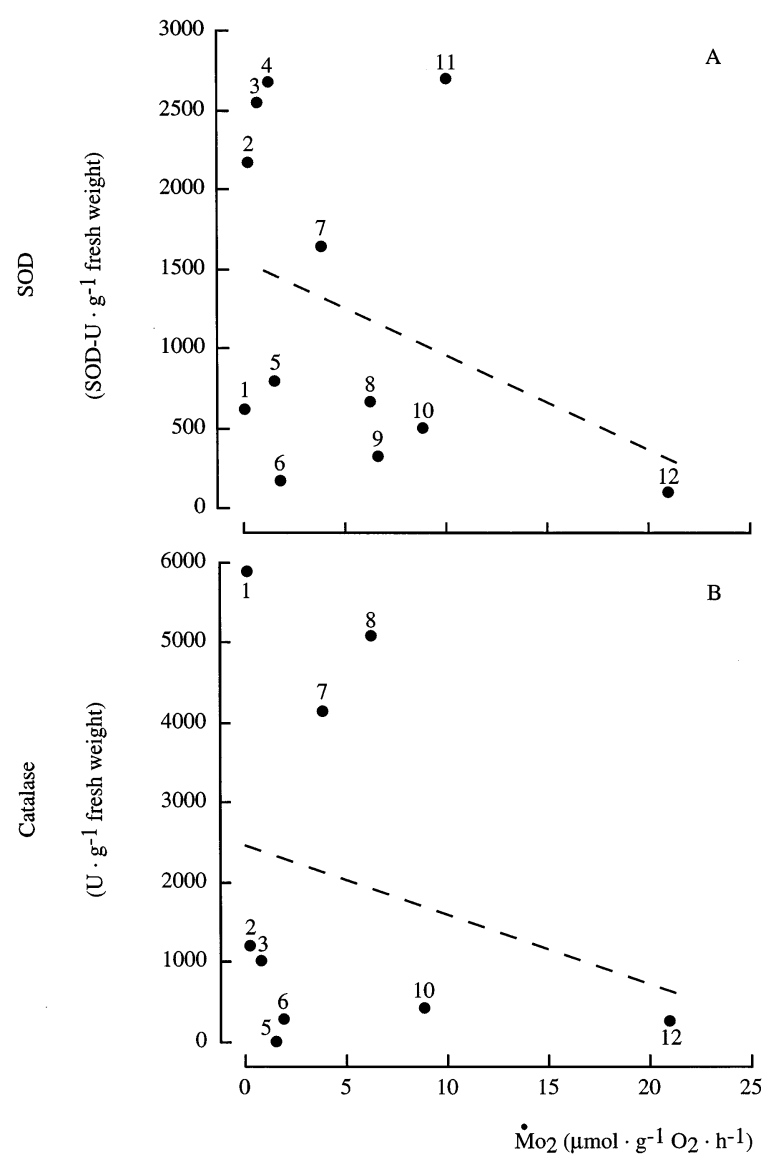

Fig. 4. Activities of superoxide dismutase and catalase in ectothermic aquatic species in relation to their metabolic rate (error bars omitted for the sake of clarity; see Table 1 for S.D. and references). SOD: $r=0.30$; catalase: $r=0.24 ; 1$, M. edulis; 2, H. filiformis; 3, S. nudus; 4, A. marina; 5, Calyptogena magnifica; 6, C. maenas; 7, G. morhua; 8, N. diversicolor; 9, P. maximus; 10, S. officinalis; 11, S. trutta; 12, L. brevis.

demonstrates that the antioxidative capacity is lower in both cephalopod species than in the fish species G. morhua and Salmo trutta with metabolic rates similar to $S$. officinalis. Even species with much lower metabolic rates like Mytilus edulis or Arenicola marina display a higher enzymatic antioxidative capacity than the cephalopods. This already casts some doubt on whether antioxidative defense is correlated with the level of metabolic rate in cephalopods.

Generally, there is no clear trend of a correlation of SOD and catalase activities with metabolic rate among the ectothermic species listed in Table 1 (Fig. 4). Similarly, no trend was found for GPX and GR activities. If compared to endothermic species (Table 1), the latter display the highest metabolic rates as well as the highest levels of SOD, GPX, and GR activities. Among invertebrates, high levels of antioxidative enzymes were found in intertidal species like A. marina, Heteromastus filiformis, Sipunculus nudus and Nereis diversicolor, which can be exposed to very high environmental $\mathrm{H}_{2} \mathrm{O}_{2}$ concentrations in summer, owing to $\mathrm{UV}$-induced radical formation in surface waters (Abele-Oeschger et al., 1994; Abele et al., 1998). Overall this comparison shows that among ectothermic species and at least for the two investigated cephalopods $S$. officinalis and L. brevis, a high metabolic rate does not necessarily go hand in hand with a high capacity of antioxidative enzymes.

Investigations in several mammalian species showed a clear correlation between oxygen radical production and metabolic rate. The species with the highest metabolic rate produced the highest concentrations of superoxide and $\mathrm{H}_{2} \mathrm{O}_{2}$ in mitochondria ( $\mathrm{Ku}$ et al., 1993). If this holds true also for cephalopods with their relatively high metabolic rate (Pörtner, 1994), it appears conceivable that a higher degree of oxidative damage develops due to the relatively low antioxidative capacity (see below).

\subsection{Antioxidative defense and aging}

Changes in antioxidative enzyme activities in tissues of $S$. officinalis with increasing age of the animals were not uniform. While SOD and GPX activity increased with age, catalase activity decreased and GR activity remained almost unchanged. The picture arising from the literature is similarly diverse. For example, GR activity in younger A. marina was higher than in older lugworms, while in the latter catalase activity was increased (Buchner et al., 1996). In contrast, catalase activity in $M$. edulis decreased with increasing age of the animals (Viarengo et al., 1991a). In the liver of the frog Rana perezi, the activities of catalase, GR and GPX showed no age dependence at all (López-Torres et al., 1991), while in the tissues of the housefly $M$. domestica both SOD and catalase activities were lower in older animals (Sohal et al., 1983). Nonetheless, catalase and SOD seem to influence aging. Increased activities of SOD and catalase caused by simultaneous overexpression of both enzymes in genetically engineered fruit flies Drosophila melanogaster (Orr and Sohal, 1994) or in the nematode Caenorhab- 
ditis elegans after mutation in the relevant gene (age-1; Johnson, 1990) resulted in an increased life span of both species. Therefore, decreasing activities of one or both of these enzymes with increasing age may have a detrimental effect on life span.

Changes in antioxidative enzyme activities not only vary between species, but also between tissues of a given species. For example, SOD activity increased in liver and heart of rats with increasing age, while it was lowered in the brain. At the same time, the production of oxygen radicals was increased in older compared to younger rats (Sohal et al., 1990). Such an increase in radical generation during aging was also found in other species (Sohal et al., 1983; Sawada and Carlson, 1987). Sohal et al. (1990) therefore concluded that the production rate of radicals is more important for aging than a potentially limiting capacity of antioxidative processes. This hypothesis is supported by the finding that the mitochondrial radical production in several mammalian species is negatively correlated with the maximal life span potential. Animals with the shortest life expectancy and at the same time highest metabolic rates exhibit the highest rates of radical production (Sohal et al., 1989; Ku et al., 1993). The authors concluded that faster aging is probably caused by higher radical production rates, resulting in increased cellular damage (Sohal, 1981). This is supported by the fact that the rate of lipofuscin accumulation is correlated with metabolic rate. A faster rate of lipofuscin accumulation was found in D. melanogaster with a rise in metabolic rate at increased temperature compared to animals kept at lower temperatures (Sheldahl and Tappel, 1974). Similarly, M. domestica with higher metabolic rates at elevated activity levels displayed higher lipofuscin contents than flies with low activity levels (Sohal and Donato, 1979).

If aging in S. officinalis is also accompanied by an increased generation of oxygen radicals (see above), the elevation of SOD activity with increasing age (Fig. 2) would compensate to some extent for the expected rise in superoxide formation, but lead to increased $\mathrm{H}_{2} \mathrm{O}_{2}$ formation. A decrease of catalase activity in old $S$. officinalis would then impede the degradation of the intracellular hydrogen peroxide. It seems unlikely that this loss of catalase activity was compensated for by the rise in GPX activity, because GPX activity was 800 times lower than maximal catalase activity. It has been suggested that relatively high levels of SOD combined with low levels of catalase and GPX increase not only the intracellular concentration of $\mathrm{H}_{2} \mathrm{O}_{2}$ but also the formation of hydroxyl radicals (Sohal, 1991). Due to the extreme reactivity of the hydroxyl radicals low molecular weight antioxidants may not balance this increase (Chance et al., 1979; Sohal, 1991), thus probably leading to an increase in oxidative damage.

\subsection{Indicators of oxidative stress and age}

Final evidence for the increase in oxidative stress with increasing age arises from the accumulation of MDA and lipofuscin (Leibovitz and Siegel, 1980; Halliwell and Gutteridge, 1989). An increase in MDA levels with age was found in the digestive gland of $M$. edulis (Viarengo et al., 1991a), while in the liver of $R$. perezi no age dependent change occurred (López-Torres et al., 1991). In liver and kidney of rats MDA concentrations were even lower in older animals (Cand and Verdetti, 1989). Furthermore, seasonal oscillation in MDA levels has been shown for Mytilus galloprovincialis (Viarengo et al., 1991b). In the mantle musculature of $S$. officinalis only 10 months old, animals displayed a significant increase in MDA concentration. In the mantle of the oldest animals the concentration was again in the same range as in the youngest ones, whereas MDA levels were still significantly elevated in the gill tissue. Probably, the continuous contact of this tissue with oxygen rich water leads to a higher rate of radical formation and thus to more continuous formation of MDA. The maximal concentration of MDA found in S. officinalis was $234.8 \mathrm{nmol} \mathrm{g}^{-1}$ fresh weight in the mantle musculature and $494 \mathrm{nmol} \mathrm{g}^{-1}$ fresh weight in the gill tissue. These values are considerably higher than the $81.7-89.9 \mathrm{nmol} \mathrm{g}^{-1}$ fresh weight found in the liver of $R$. perezi (López-Torres et al., 1991) or the 45.4-75.8 $\mathrm{nmol} \mathrm{g}^{-1}$ fresh weight found in the bivalves $M$. edulis and Adamussium colbecki (Viarengo et al., 1991a, 1995). The considerably higher concentration of MDA in the tissues of $S$. officinalis is probably favored by the relatively low level of antioxidative protection and the high metabolic rate.

The decrease in MDA concentrations in older animals might be caused by the transformation of MDA into lipofuscin (Cand and Verdetti, 1989). Accordingly, lipofuscin concentrations were sig- 
nificantly elevated in both mantle musculature and brain of old specimens. An age related increase in lipofuscin levels has also been found in several species of crustaceans (Nicol et al., 1991; Sheehy et al., 1994), fish (Vernet et al., 1988) and insects (Sohal, 1981). Since lipofuscin levels are not expressed as definite concentrations but rather in relative units which also differ among studies, a comparison of levels between species is not possible. Furthermore, it seems that lipofuscin does not accumulate continuously over time. In the Australian crayfish Cherax quadricarinatus, Sheehy et al. (1994) found fluctuations in lipofuscin levels, which are most likely related to seasonal oscillations in environmental parameters. A slowing down of lipofuscin accumulation appears to occur in older crustaceans, probably related to a lower metabolic rate in older/larger animals (Sheehy, 1992). In our study of laboratory maintained cuttlefish, environmental influences were largely excluded. The exponential rise of lipofuscin levels over time (Fig. 3) suggests that lipofuscin accumulation is more uniform than MDA accumulation. This indicates not only that lipofuscin is a better indicator of age related stress than MDA, but also that lipofuscin accumulation and thus oxidative change occur at a larger rate in aged animals. However, although the exponential rise in lipofuscin levels may reflect limits of tolerance to oxidative stress, it is not clear until now which levels of MDA and especially lipofuscin indicate irreversible damage to the organism. Therefore, no definite conclusions can be drawn yet to what extent these processes contribute to the short life expectancies of cephalopods.

\section{Conclusions and perspectives}

Similar to mammalian species (Sohal et al., 1989; $\mathrm{Ku}$ et al., 1993), the high metabolic rate of cephalopods correlates with a high rate of radical production. The comparatively low level of enzymatic antioxidant defense correlates with an increased level of oxidative damage, reflected by much higher levels of MDA in gill and mantle tissue of cephalopods than in other species. It also correlates with an exponential accumulation of lipofuscin indicating oxidative stress is higher in old specimens. This may be caused by a drop in catalase at elevated SOD activities in older animals, which favors oxygen radical formation and, obviously, oxidative stress. As a corollary, the relatively low antioxidative status found in cephalopods is in line with their short life expectancy. This conclusion is supported by the observation that antioxidative status is lower in the squid $L$. brevis than in the cuttlefish $S$. officinalis, which, accordingly, lives almost twice as long as the squid. The question arises why antioxidative defense is not brought to a higher level in order to prolong cephalopod life. An explanation may be that the level of antioxidative protection is set to a level just high enough to allow for sufficient life span. Therefore, future research should focus on whether this low level of antioxidative protection is typical for cephalopods and, from a more general point of view, whether it is adjusted to a level just high enough to support the programmed life span of a species.

\section{Acknowledgements}

The excellent technical and logistical help by the staff of the Marine Biomedical Institute is gratefully acknowledged. We would like to thank Dr T.A. Heming from the Department of Internal Medicine at the University of Texas, Galveston for the use of a fluorimeter in his laboratory. Special thanks go to Tanja Buchner for help with the methodology. This research was supported by grants of the Deutsche Forschungsgemeinschaft to H.O. Pörtner (Po 278). Alfred-Wege-neu-Institute publication no. 1710 .

\section{References}

Abele, D., Großpietsch, H., Pörtner, H.O., 1998. Temporal fluctuations and spatial gradients of environmental $\mathrm{P}_{\mathrm{O}_{2}}$, temperature, $\mathrm{H}_{2} \mathrm{O}_{2}$ and $\mathrm{H}_{2} \mathrm{~S}$ in its intertidal habitat trigger enzymatic antioxidant protection in the capitellid worm Heteromastus filiformis. Mar. Ecol. Prog. Ser. 163, 179-191.

Abele-Oeschger, D., Oeschger, R., Theede, H., 1994. Biochemical adaptations of Nereis diversicolor (Polychaeta) to temporarily increased hydrogen peroxide levels in intertidal sandflats. Mar. Ecol. Prog. Ser. 106, 101-110.

Aebi, H.E., 1985. Catalase. In: Bergmeyer, H.U., Bergmeyer, J., Graßl, M. (Eds.), Methods of Enzymatic Analysis. Vol VIII. Verlag Chemie, Weinheim, 1985, pp. 273-286. 
Arp, A.J., Childress, J.J., Fisher, C.R., 1984. Metabolic and blood gas transport characteristics of the hydrothermal vent bivalve Calyptogena magnifica. Physiol. Zool. 57, 648-662.

Blum, J., Fridovich, I., 1984. Enzymatic defense against oxygen toxicity in the hydrothermal vent animals Riftia pachyptila and Calyptogena magnifica. Arch. Biochem. Biophys. 228, 617-620.

Boutilier, R.G., 1998. Physiological ecology in cold ocean fisheries: a case study in Atlantic cod. In: Pörtner, H.O., Playle, R.C. (Eds.), Cold Ocean Physiology. Cambridge University Press, Cambridge, 1998, pp. 464-489.

Brand, A.R., Roberts, D., 1973. The cardiac responses of the scallop Pecten maximus (L.) to respiratory stress. J. Exp. Mar. Biol. Ecol. 13, 29-43.

Buchner, T., Abele-Oeschger, D., Theede, H., 1996. Aspects of antioxidant status in the polychaete Arenicola marina: tissue and subcellular distribution, and reaction to environmental hydrogen peroxide and elevated temperature. Mar. Ecol. Prog. Ser. 143, 141-150.

Calow, P., 1987. Fact and Theory - an Overview. In: Boyle, P.R. (Ed.), Cephalopod Life Cycles Vol. II. Academic Press, London, 1987, pp. 351-365.

Cand, F., Verdetti, J., 1989. Superoxide dismutase, glutathione peroxidase, catalase, and lipid peroxidation in the major organs of the aging rats. Free Rad. Biol. Med. 7, 59-63.

Chance, B., Sies, H., Boveris, A., 1979. Hydroperoxide metabolism in mammalian organs. Physiol. Rev. 59, 527-605.

Elstner, E.F., 1990. Der Sauerstoff. Biochemie, Biologie, Medizin. Wissenschaftsverlag, Mannheim Wien Zürich.

Ettershank, G., 1983. Age structure and cyclical annual size change in the Antarctic krill, Euphausia superba Dana. Polar Biol. 2, 189-193.

Ettershank, G., 1984. A new approach to the assessment of longevity in the Antarctic krill, Euphausia superba. J. Crust. Biol. 4, 295-305.

Finke, E., Pörtner, H.O., Lee, P.G., Webber, D.M., 1996. Squid (Lolliguncula brevis) life in shallow waters: Oxygen limitation of metabolism and swimming performance. J. Exp. Biol. 199, 911-921.

Forsythe, J.W., DeRusha, R.H., Hanlon, R.T., 1994. Growth, reproduction and life span of Sepia officinalis (Cephalopoda: Mollusca) cultured through seven consecutive generations. J. Zool. Lond. 233, $175-192$.

Foster, A.R., Hall, S.J., Houlihan, D.F., 1993. The effects of temperature acclimation on organ/tissue mass and cytochrome c oxidase activity in juvenile cod (Gadus morhua). J. Fish Biol. 42, 947-957.

Gamble, S.C., Goldfarb, P.S., Porte, C., Livingstone, D.R., 1995. Glutathione peroxidase and other an- tioxidant enzyme function in marine invertebrates (Mytilus edulis, Pecten maximus, Carcinus maenas and Asterias rubens). Mar. Env. Res. 39, 191-195.

Goldberg, D.M., Sparner, R.J., 1987. Glutathione reductase. In: Bergmeyer, H.U., Bergmeyer, J., Graß1, M. (Eds.), Methods of Enzymatic Analysis. Vol. III. Verlag Chemie, Weinheim, pp. 258-265.

Günzler, A., Flohé, L., 1985. Glutathione peroxidase. In: Greenwald, R.A. (Ed.), CRC Handbook of Methods for Oxygen Radical Research. CRC Press, Boca Raton, FL, pp. 285-289.

Halliwell, B., Gutteridge, J.M.C., 1989. Free Radicals in Biology and Medicine. Clarendon Press, Oxford.

Harman, D., 1956. A theory based on free radical and radiation chemistry. J. Geront. 11, 298-300.

Hill, K.T., Womersley, C., 1991. Critical aspects of fluorescent age-pigment methodologies: modification for accurate analysis and age assessments in aquatic organisms. Mar. Biol. 109, 1-11.

Hixon, R.F., Hanlon, R.T., Hulet, W.H., 1981. Growth, fecundity and estimated life span of three loliginid squid species in the northwestern Gulf of Mexico. J. Shellfish Res. 1, 116.

Johansen, K., Brix, O., Kornerup, S., Lykkeboe, G., 1982. Factors affecting $\mathrm{O}_{2}$-uptake in the cuttlefish, Sepia officinalis. J. Mar. Biol. Ass. UK 62, 187-191.

Johnson, T.E., 1990. Increased life-span of age-1 mutants in Caenorhabditis elegans and lower Gompertz rate of aging. Science 249, 908-912.

Kristensen, E., 1983. Ventilation and oxygen uptake by three species of Nereis (Annelida: Polychaeta) II. Effects of temperature and salinity changes. Mar. Ecol. Progr. Ser. 12, 299-306.

Ku, H.H., Brunk, U.T., Sohal, R.S., 1993. Relationship between mitochondrial superoxide and hydrogen peroxide production and longevity of mammalian species. Free Rad. Biol. Med. 15, 621-627.

Leibovitz, B.E., Siegel, B.V., 1980. Aspects of free radical reactions in biological systems: aging. $\mathrm{J}$. Geront. 35, 45-56.

Lemaire, P., Viarengo, A., Canesi, L., Livingstone, D.R., 1993. Pro-oxidant and antioxidant processes in gas gland and other tissues of cod (Gadus morhua). J. Comp. Physiol. 163B, 477-486.

López-Torres, M., Pérez-Campo, R., Barja de Quiroga, G., 1991. Effect of natural ageing and antioxidant inhibition on liver antioxidant enzymes, glutathione system, peroxidation, and oxygen consumption in Rana perezi. J. Comp. Physiol. 160B, 655-661.

López-Torres, M., Pérez-Campo, R., Rojas, C., Cadenas, S., Barja, G., 1993. Maximum life span in vertebrates: relationship with liver antioxidant enzymes, glutathione system, ascorbate, urate, sensitivity to peroxidation, true malondialdehyde, in vivo $\mathrm{H}_{2} \mathrm{O}_{2}$, and basal and maximum aerobic capacity. Mech. Ageing Dev. 70, 177-199. 
Marklund, S., Marklund, G., 1974. Involvement of the superoxide anion radical in the autoxidation of pyrogallol and a convenient assay for superoxide dismutase. Eur. J. Biochem. 47, 469-479.

Messenger, J.B., Nixon, M., Ryan, K.P., 1985. Magnesiumchloride as an anaesthetic for cephalopods. Comp. Biochem. Physiol. 82C, 203-205.

Newell, R.C., Bayne, B.L., 1973. A review of temperature and metabolic acclimation in intertidal marine invertebrates. Neth. J. Sea Res. 7, 421-433.

Nicol, S., 1987. Some limitations on the use of lipofuscin ageing technique. Mar. Biol. 93, 609-614.

Nicol, S., Stolp, M., Hosei, G.W., 1991. Accumulation of fluorescent age pigments in a laboratory population of Antarctic krill Euphausia superba Dana. J. Exp. Mar. Biol. Ecol. 146, 153-161.

O’Dor, R.K., Webber, D.M., 1986. The constraints on cephalopods: why squid aren't fish. Can. J. Zool. 64, 1591-1605.

Orr, W.C., Sohal, R.S., 1994. Extension of life-span by overexpression of superoxide dismutase and catalase in Drosophila melanogaster. Science 263, 1128-1130.

Pörtner, H.O., Heisler, N., Grieshaber, M.K., 1985. Oxygen consumption and mode of energy production in the intertidal worm Sipunculus nudus L.: definition and characterization of the critical $\mathrm{P}_{\mathrm{O}_{2}}$ for an oxyconformer. Respir. Physiol. 59, 361-377.

Pörtner, H.O., 1994. Coordination of metabolism, acidbase regulation and haemocyanin function in cephalopods. In: Pörtner, H.O., O’Dor, R.K., MacMillan, D. (Eds.), Physiology of Cephalopod Molluscs - Lifestyle and Performance Adaptations. Gordon and Breach Publishers, Basel, pp. $131-148$.

Pörtner, H.O., 1997. Oxygen limitation of metabolism and performance in pelagic squid. In: Hawkin, L.E., Hutchinson, S., (Eds.), Proceedings of the Thirtieth European Marine Biological Symposium, pp. 4556.

Reiss, U., Gershon, D., 1976. Rat-liver superoxide dismutase. Eur. J. Biochem. 63, 617-623.

Sawada, M., Carlson, J.C., 1987. Changes in superoxide radical and lipid peroxide formation in the brain, heart and liver during the lifetime of the rat. Mech. Ageing Dev. 41, 125-137.

Sheehy, M.R.J., 1992. Lipofuscin age-pigment accumulation in the brains of ageing field- and laboratoryreared crayfish Cherax quadricarinatus (von Martens) (Decapoda: Parastacidae). J. Exp. Mar. Biol. Ecol. 161, 79-89.

Sheehy, M.R.J., Greenwood, J.G., Fielder, D.R., 1994. More accurate chronological age determination of crustaceans from field situations using the physiological age marker, lipofuscin. Mar. Biol. 121, $237-$ 245 .
Sheldahl, J.A., Tappel, A.L., 1974. Fluorescent products from aging Drosophila melanogaster: an indicator of free radical lipid peroxidation damage. Exp. Geront. 9, 41-43.

Sohal, R.S., 1991. Hydrogen peroxide production by mitochondria may be a marker of aging. Mech. Ageing Dev. 60, 189-198.

Sohal, R.S., Donato, H., 1979. Effect of experimental prolongation of life span on lipofuscin content and lysosomal enzyme activity in the brain of the housefly, Musca domestica. J. Geront. 34, 489-496.

Sohal, R.S., 1981. Metabolic rate, aging, and lipofuscin accumulation. In: Sohal, R.S. (Ed.), Age Pigments. Elsevier/North-Holland Biomedical Press, Amsterdam, 1981, pp. 303-316.

Sohal, R.S., Farmer, K.J., Allen, R.G., Cohen, N.R., 1983. Effect of age on oxygen consumption, superoxide dismutase, catalase, glutathione, inorganic peroxides and chloroform-soluble antioxidants in the adult male housefly, Musca domestica. Mech. Ageing Dev. 24, 185-195.

Sohal, R.S., Svensson, I., Sohal, B.H., Brunk, U.T., 1989. Superoxide anion radical production in different animal species. Mech. Ageing Dev. 49, 129-135.

Sohal, R.S., Arnold, L.A., Sohal, B.H., 1990. Age-related changes in antioxidant enzymes and prooxidant generation in tissues of the rat with special reference to parameters in two insect species. Free Rad. Biol. Med. 10, 495-500.

Sohal, R.S., Weindruch, R., 1996. Oxidative stress, caloric restriction, and aging. Science 273, 59-63.

Sommer, A., 1998. Mechanismen und Grenzen der Temperaturanpassung beim Pierwurm Arenicola marina (L.). Ber Polarforsch 285, 168 pp.

Stadtman, E.R., 1992. Protein oxidation and aging. Science 257, 1220-1224.

Storey, K.B., 1996. Oxidative stress: animal adaptations in nature. Braz. J. Med. Biol. Res. 29, 1715-1733.

Taylor, E.W., Butler, P.J., Al-Wassia, A., 1977. Some responses of the shore crab, Carcinus maenas (L.) to progressive hypoxia at different acclimation temperatures and salinities. J. Comp. Physiol. 122B, 39-42.

Uchiyama, M., Mihara, M., 1978. Determination of malonaldehyde precursor in tissues by thiobarbituric acid test. Anal. Biochem. 86, 271-278.

Vernet, M., Hunter, J.R., Vetter, R.D., 1988. Accumulation of age pigments (lipofuscin) in two cold-water fishes. Fish Bull. 86, 401-407.

Viarengo, A., Canesi, L., Pertica, M., Livingstone, D.R., Orunesu, M., 1991a. Age-related lipid peroxidation in the digestive gland of mussels: the role of the antioxidant defense systems. Experientia 47, $454-457$.

Viarengo, A., Canesi, L., Pertica, M., Livingstone, D.R., 1991b. Seasonal variations in the antioxidant 
defence systems and lipid peroxidation of the digestive gland of mussels. Comp. Biochem. Physiol. 100C, 187-190.

Viarengo, A., Canesi, L., Garcia Martinez, P., Peters, L.D., Livingstone, D.R., 1995. Pro-oxidant and antioxidant defence systems in the tissues of the
Antarctic scallop (Adamussium colbecki) compared with the Mediterranean scallop (Pecten jacobeus). Comp. Biochem. Physiol. 111B, 119-126.

von Boletzky, S., 1983. Sepia officinalis. In: Boyle, P.R. (Ed.), Cephalopod Life Cycles, Vol. I. Academic Press, London, pp. 31-52. 